\title{
Gaps in the Education Management in Indonesia that are not Following Existing Laws in Indonesia
}

\author{
Solihin ${ }^{1}$, Rineke Sara ${ }^{2}$ \\ University of Borobodur ${ }^{1,2}$ \\ \{solihinunboro@gmail.com ${ }^{1}$, rineke_sara@borobudur.ac.id² ${ }^{2}$,
}

\begin{abstract}
Education is all learning experiences that take place in all environments and throughout life that every human goes through and affects the growth of each individual. As for the legal foundations governing education itself. Every citizen of the country is entitled to the same teaching. Many rules govern an education. For education in areas, especially areas that are still included in the category of interior or areas that are still far from the city. They are still having trouble getting a proper education. The absence of sufficient facilities and infrastructure for teaching and learning activities, especially in rural areas. Lack of teacher interest in educating or opening a school in remote or remote areas. The method used in this research is the field observation method, conducting interviews with teachers and rural communities, literature study to obtain materials that are following what is being studied. The purpose of this research is the existence of laws that enforce every rural community so that they get a decent education and get the same teaching. This study concludes that there are still some areas that have not received proper teaching and a lack of facilities and infrastructure in education, especially in remote or remote areas.
\end{abstract}

Keywords: Education; Legal Basis; Rural Areas; KBM

\section{Introduction}

Education in a broad sense is all learning experiences that take place in all environments and throughout life that each human goes through and affects individual growth [1]. Every human being has the right to receive the same education teaching, whether people who live in cities or those who live in villages. For this reason, every education provision must be under the existing provisions. Education is a must for humans. Education is a necessity of life which is a human right that must be protected. Every citizen (individual) has the same right to get an education, therefore, in the provision of education, laws and regulations are required by the State or the government.

The delivery of education must be based on the foundation of human rights by the applicable laws. The delivery of education, including educators, teachers, as people who are responsible for delivering education, need to understand the legal basis for providing education. By understanding the legal foundation they are better prepared to accept the adjustments that need to be made and the possibility of innovation in education. Pancasila, as stated in the preamble to the 1945 Constitution, constitutes the personality, purpose, and view 
of the life of the Indonesian people, therefore the reference that must be the legal basis for the national education system is Pancasila. To realize the process of implementing national education for the people of the nation and state of Indonesia, the MPRS/MPR decrees and Government Decrees and Law of the Republic of Indonesia No.2 of 1989 concerning the National Education System, Law of the Republic of Indonesia No.30 2005 concerning Teachers and Lecturers, and laws, other government decrees regarding the national education system for the people of the Indonesian nation and state.

Teachers as the implementation of education should pay attention to government policies. Therefore, the teacher's role, both directly and indirectly, must support all government policies, namely to prepare Indonesian people for future life. For this purpose, teachers must be able to keep up with developments and changes in government policies. Not only directly related to the field of education but even from various aspects of life that allow them to deliver students to understand their rights and obligations. Following the demands of the needs and development and progress of human life, the teacher has a reference or guideline in carrying out his duties as outlined in law No. 14 of 2005 concerning teachers and lecturers. In the law, the position, duties, functions, and the role of teachers and lecturers as professionals. This law is the legal basis for teachers and lecturers in carrying out their duties in addition to laws and other government regulations or decisions.

The main legal basis in the process of implementing national education for the people of the nation and the Indonesian State is Pancasila and the 1945 Constitution and is supported by laws and decrees of the MPRS/MPR and decisions made by the government. In article 31 paragraph 4 (four) of the 1945 Constitution and paragraph 1 (one) of Law No. 20 of 2003, the government's responsibility for education has been regulated. In practice, the government is less responsible as a whole about the teaching and learning process for the delivery of education. The government is more focused on paying attention to education organized by the government or what is commonly called public schools and less paying attention to the implementation by the public or the private sector. In this case, the government is discriminative against public and private schools. This can be seen from the government assistance and facilities and infrastructure for public schools and the very minimum government facilities for private schools [2].

\section{Methodology}

In this study, using research, namely field observations, interviews with several related people, literature study under the research.

\subsection{Observation}

Conducting observations or looking into the field directly about the education process carried out by the government, both public schools and public/private schools, both in urban areas and in rural areas and even in rural areas related to the education program carried out by the government.

\subsection{Interview}

Conducting interviews related to this research to parties who are involved in the process, or the administration of education both to those who teach or who work in public schools and 
private/community schools not only in cities but also conducting interviews with parties in rural and inland.

\subsection{Literature Review}

Look for books, articles, etc. related to this research. Adjusting this research so as not to leave research in the process of compiling scientific papers.

\section{Result and Discussions}

Education according to Law no. 20 of 2003 concerning the National Education System is a conscious and planned effort to create an atmosphere of learning and the learning process so that students actively develop their potential to have religious-spiritual strength, self-control, personality, intelligence, noble character, and skills needed by themselves, the community. , nation and state [3].

In the national education system, everything is well planned to support the learning process to develop every potential and skill of each student. National education is education based on Pancasila and the 1945 Constitution of the Republic of Indonesia which is rooted in religious values, Indonesian national culture, and responsive to the demands of changing times.

The national education system itself is an integrated component of education to achieve the goals of national education following the applicable regulations for the education process in the country of Indonesia. The education system that has been designed is useful for regulating every process of education implementation, both for public schools and for private schools, both in cities and in rural areas, all must be following the applicable education system.

In particular, education is a conscious effort made by the family, community, and government, through guidance, teaching, and/or training activities, which take place inside and outside of school throughout life, to prepare students to play roles in various environments. live appropriately in the future. Education is a conscious effort that always departs from several bases and transfers certain principles. These foundations and hopes are very important because education is the main pillar of human development and certain national societies. In general, education is all learning experiences that take place in all environments and throughout life [4].

The foundation of education can briefly be said as a place of rest or a basis in carrying out a critical analysis of the principles and realities of education policies and practices. The study of critical analysis of these principles and realities can be used as a fulcrum or basis to find effective and useful education policies and practices. In other words, it can be said that the foundation of education is the basis for efforts to develop education in all its aspects [5]. Several foundations can be used as a fulcrum in carrying out a critical analysis of principles and realities to make education policies and practices, these bases include:

a. Philosophical Basis. The philosophical foundation is a foundation related to the meaning or essence of education that seeks to examine the main problems in education such as what education is, why education is needed, and what should be the purpose of education. In this connection, the philosophical basis is a foundation that is based on or is philosophical. By its nature, the foundation of philosophy is something radically comprehensive and conceptual that produces conceptions about life and the world.

b. Sociological Basis. A socio-logical basis is a social event that takes place in the background of social interaction because education cannot be separated from the efforts 
and processes of mutual influence between the individuals involved in it. Referring to two terms, namely educators and students as seen from their position in social interaction. Education process to show who is an educator and who is a student permanently because both of them can change function and position.

c. Legal Foundation. A legal basis is a multidimensional event, concerned with various aspects of human life and society. Education policies, administration, and development in society need to be focused on a clear and legitimate legal basis. By being based on law, policies for the administration and development of education can be avoided from various clashes of needs. At least on a legal basis, all the rights and obligations of educators can be preserved.

d. Cultural Foundation. The cultural foundation is part of cultural events. This is because education and culture have a reciprocal relationship. Culture can be preserved and developed by passing on from one generation to the next through education, both informal, non-formal, and formal education.

e. Psychological Basis. The psychological foundation involves aspects of the human psyche, which is one of the important foundations in the field of education. This foundation is aimed at human understanding, especially concerning the human learning process. Understanding students, especially those related to psychological aspects, is one of the keys to success in education.

f. Scientific and Technological Foundation. The scientific and technological foundations of Education are closely related to science, technology, and arts. In the form of learning, there are links with science, art, and technology in the learning process. Scientific and technological foundations are used as the basis for determining education policies and practices.

g. Economic Basis. In general, humans cannot be separated from economic needs, because basic or basic human needs require economy. Economic growth is high and state income increases even though the foreign debt is quite large and the income of the small people is still minimal. Economic development is an influence on the field of education.

h. Historical Foundation. The historical foundation provides a very important role because from history it can make a direction of thought in the present and can lead to better education in the future. So that in the process of providing education to be better, we must look at the past process to be processed back to a better direction and be applied in the future. The history of education is a comparison material for advancing the education of a nation.

i. Religious Foundation. The religious foundation is the basis of comparison which is the most basic of the foundations of Education because the foundation of religion is the foundation created by God. Every process of providing education must exist and students must attend religious education. Religious education is the right of every student, not a state or an organization.

In the process of implementing education in the country of Indonesia, it is still far from perfect and it is still far from the basics of law in effect in Indonesia. Why is it said that it is still far from perfect because there are still many areas that have not been able to enjoy a good and adequate education process such as areas in rural areas, or in the interior which are still far from roads and far from capitals. If you look at those who live in rural areas and the interior, they have to walk long distances. When they have to go to school and go to school, there are still many buildings that need to be repaired. Unlike in urban areas, they can already enjoy the infrastructure at school properly, even the facilities available in urban schools are better and more complete in urban areas than in rural or remote areas. Why can this happen is because 
the government is doing a good education gap for public schools which takes precedence from the government over private schools.

Even in terms of assistance, public schools are prioritized over private schools. Children in rural areas or their inland areas cannot enjoy good facilities provided by the school, be it in terms of buildings, books, sports facilities, and so on. Under applicable regulations that all Indonesian people are entitled to the same education. Still not following applicable regulations. Children in rural areas or their inland areas cannot enjoy good facilities provided by the school, be it in terms of buildings, books, sports facilities, and so on. By the applicable regulations that all Indonesian people are entitled to the same education. Still not following applicable regulations. Children in rural areas or their inland areas cannot enjoy good facilities provided by the school, be it in terms of buildings, books, sports facilities, and so on. By applicable regulations that all Indonesian people are entitled to the same education. Still not under applicable regulations.

The government still lacks attention to rural or hinterland areas. Many potential children cannot go to school because of the economy, school distances are far, school facilities are incomplete, and so on. Potential must be explored in schools if schools cannot describe the best for their students they will also find it difficult to exploit their potential. In the world of school education in urban areas is more advanced than in rural areas or the interior. The way of teaching students in urban areas is much different from that in rural areas.

\section{Conclusion}

This research concludes that there are still many processes for the implementation of education that are not following the laws in force in Indonesia. This is all due to the distribution of aid from the government which prioritizes public schools rather than private schools. In terms of facilities, assistance is very different from public schools and private schools. Children in areas that are difficult to reach will find it difficult to receive education because of the lack of distribution of assistance to rural or remote areas. Education carried out by rural or remote areas must be obtained with difficulty. They have to walk many kilometers to go to school and gain knowledge because the distance between the school and the house is still far away due to difficult road access.

The government must look at those who live in rural or remote areas. So that those who live in rural areas or the interior also experience education under applicable legal standards. The country wants to move forward and improve the process of providing education that is evenly distributed throughout the country so that their children can receive a proper education. The backbone of the country is in children's education which can advance and prosper people's lives. Education can be evenly distributed throughout the country, of course, the economy of every citizen is in good condition and can reduce the poverty rate in Indonesia. Therefore, the existing law must be implemented to achieve the aspirations of the Indonesian nation, namely to educate all Indonesian people. So a good step that must be used is to level education not only in urban areas but also in rural areas as well, especially in inland areas that are difficult to reach by vehicles. The teaching methods are different from those in cities from those in the countryside, or the inside. Teaching methods in cities are more modern because they are assisted by good facilities than in rural or remote areas.

The government is working hard so that education policies can be distributed evenly to all Indonesian people. Through education, the Indonesian nation will be even better. Through education, there will be people who can advance the Indonesian nation and can guide the 
Indonesian nation in a better direction. There is a lot of potential for children in the future that the state must take advantage of for the common interest of Indonesia.

\section{References}

[1] B. Maunah, "Education Foundation.pdf." pp. 5-6, 2009, [Online]. Available: http://repo.iain-tulungagung.ac.id/6184/.

[2] Maryanto, "The Politics of Education Law," Civis, J. Ilm. Ii, Vol. Indonesia. Government, vol. II, no. 1, pp. 199-216, 2012.

[3] 2003 RI Law NO.20, "Law of the Republic of Indonesia No. 20 on the National Education System," Jakarta Directorate of Educators. Intermediate General, p. 6, 2003, [Online]. Available: http://stpi-binainsanmulia.ac.id/wpcontent/uploads/2013/04/Lamp_2_UU20-2003-Sisdiknas.doc.

[4] A. Kallang, "The Relationship between Education and Law in Human Welfare," Exposure J. Researcher. Huk. and Educators., vol. 16, no. 2, p. 402, 2019, doi: 10.30863 / expose.v16i2.100.

[5] S. Nurmalita, "The Nature of Education and the Foundation of Education in the Learning Process," J. Mater. Process. Technol., vol. 1, no. 1, pp. 1-8, 2018, [Online]. Available:

http://dx.doi.org/10.1016/j.cirp.2016.06.001\%0Ahttp://dx.doi.org/10.1016/j.powtec.20 16.12.055\%0Ahttps://doi.org/ 10.1016 / j.ijfatigue.2019.02.006\% 0Ahttps: //doi.org/10.1016/j.matlet.2019.04.024\%0Ahttps:

//doi.org/10.1016/j.matlet.2019.127252\%0Ahttp: // dx. doi. o. 